\title{
Contents, Vol. 22, 1990
}

\section{No. 1 Editorial}

Hockwin, $0 \quad 1$

Original Paper

Prostanoids in the Vitreous of Diabetic and Nondiabetic Human Eyes with Retinal Detachment

Naveh, N.; Belkin, M.; Ben-Chaim, O.; Weissman, C; Treister, G 3

Effects of Endotoxin and Anti-Inflammatory Agents on Superoxide Dismutase in the

Rabbit Iris

Recasens, J.F.; Green, K 12

Alterations of the Cat's Electroretinogram Induced by the Lesioning of the IndoleamineAccumulating Amacrine Cells

Hamasaki, D.I.; Tucker, G.S.; Maguire, G.W

Column Chromatography, Sodium Dodecyl Sulfate-Polyacrylamide Gel Electrophoresis and Two-Dimensional Electrophoresis of Pig Lens Crystallins

Vidal, P.; Cabezas-Cerrato, J 31

Relationship between Plasma and Tear Fluoride Levels in Rabbit and Man

Chan, J.T.; Cheeks, L.; Slagle, T.; Green, K 39

Nucleotide Levels in Human and Bovine Lenses: A Study on Regional postmortem

Changes

Pau, H.; Deussen, A 45

Proliferation of Corneal Epithelial and Endothelial Cells in the Trabecular Region of

Human Donor Corneas in Organ Culture

Zagórski, Z.; Holbach, L.; Rummelt, C; Gossler, B.; Naumann, G.O.H

Antigenic Expression of Neuron-Associated Class III Beta-Tubulin Isotype (hß4) and

Microtubule-Associated Protein 2 (MAP2) by the Human Retinoblastoma Cell Line

WERI-Rb 1. A Comparative Immunoblot and Immunocytochemical Study

Gass, P.; Frankfurter, A.; Katsetos, CD.; Herman, M.M.; Donoso, L.A.; Rubinstein, L.J. 57

Bilateral Retinal Responses after Traumatic Injury of One Eye in Mice. A Histopathologic and Immunohistochemical Study

Yew, D.T.; Yang, Q.D.; Mak, N.Y.; Au, C.Y.W.; Li, W.W.Y; Liu, W.K 67

No. 2 Acidic Fibroblast Growth Factor Distribution in Normal Human Eye and Possible

Implications in Ocular Pathogenesis Baudouin, C; Fredj-Reygrobellet, D.; Caruelle, J.-P.;

Barritault, D.; Gastaud, P.;

Lapalus, $\mathrm{P} \quad 73$

Alterations of Urea-Insoluble Membrane Fraction, MP26, of Emory Mouse Lenses in Aging and

Cataractogenesis

Lo, W.-K.; Kuck, J.F.R

'H Magnetic Resonance Imaging Study of Bovine Ocular Tissue

Williams, T.R.; Perry, B.C.; Koenig, J.L

89

IV Contents 
Clinical Patterns of Ocular Anaphylaxis in Guinea Pigs Passively Sensitized with IgGl Antibody

Leonardi, A.; Briggs, R.M.; Bloch, K.J.; Allansmith, M.R 95

Effect of Dietary Ascorbic Acid on Heat-Induced Eye Lens Protein Damage in Guinea

Pigs

Tsao, C.S.; Xu, L.-F.; Young, M 106

Pharmacologic Modulation of Acute Uveitis with Aminonicotinamide

Marak, G.E., Jr.; Sery, T.W.; Gregerson, D.; Donoso, L.A.; Rao, N.A

Retinal Cyclic GMP and AMP in Rod-Cone Dysplasia: Comparison of Assays in Fixed and Unfixed Retinal Tissues

Acland, G.M.; Fletcher, R.T.; Chader, G.J.; Aguirre, G.D 117

Changes in the Antibacterial Activity of Melanin-Bound Drugs

Fukuda, M.; Sasaki, K 123

Immunohistochemical Demonstration of Tenascin in the Normal Human Limbus with

Special Reference to Trabeculectomy

Tervo, T.; Setten, G.-B. van; Lento, I.; Tervo, K.; Tarkkanen, A.; Virtanen, I. .... 128 Intraocular

Lens Implantation following Cataract Extraction in Fuchs' Heterochromic

Uveitis

Al Samarrai, A.R.A 134

No. 3- Determination of the Interval during Which One Application of Compound 48/80 to theRat Conjunctiva Influences the Response to a Second ApplicationAllansmith, M.R.; Baird, R.S.; Barney, N.P.; Ross, R.N.; Bloch, K.J 137

Type VI Collagen in Healing Rabbit Corneal Wounds

Murata, Y.; Yoshioka, H.; Kitaoka, M.; Iyama, K.; Okamura, R.; Usuku, G

Mechanism of Coloration of Human Lenses Induced by Near-Ultraviolet-Photo-Oxidized3-

Hydroxykynurenine (With 1 color plate)Tomoda, A.; Yoneyama, Y.; Yamaguchi, T.; Shirao, E.;

Kawasaki, K 152

The Decrease of Free Epsilon-Amino Groups in Senile and Diabetic Cataracts

Simonelli, F.; Cotticelli, L.; Iura, A.; Manna, C; Nesti, A.; Rinaldi, E.; Auric-chio, G 160

Bovine Lens Membrane Proteins: MP70, MP64, and MP38 are Products of the SameGeneRao,

G.N.; Gutekunst, K.A.; Church, R.L 166

Effects of Fibroblast Growth Factor and Chondroitin Sulfate on Predamaged

CornealEndothelium. An Organ Culture StudyLin, C.-P.; Böhnke, M.; Draeger, J 173

Frequency Distribution of the Time Interval between Quick Phase Nystagmic Eye

MovementsBosone, G.; Reccia, R.; Roberti, G.; Russo, P 178

Effects of Ultraviolet B Irradiation on Lenticular Riboflavin Metabolism and High-Molecular-

Weight-Protein AggregationHirano, H.; Obara, Y.; Katakura, K.; Ono, S 183

Flow Cytometry Measurement of Nuclear RNA Content in Uveal Melanoma

Chen, T.C.; Char, D.H.; Waldman, F.; Juster, R.P 187

Iron-Binding Proteins in the Human Vitreous: Lactoferrin and Transferrin in Health and

inProliferative Intraocular DisordersWeller, M.; Clausen, R.; Heimann, K.; Wiedemann, P 194

Contents

$\mathrm{V}$

No. 4 Inhibition of Posterior Capsule Opacification by 5-Fluorouracil in Rabbits

Ruiz, J.M.; Medrano, M.; Alió, J.L 201 
Histology of Ocular Late-Phase Reaction in Guinea Pigs Passively Sensitized with IgG 1 Antibodies

Leonardi, A.; Bloch, K.J.; Briggs, R.; Allansmith, M.R 209

Seasonal Variations of Retinal Detachment among Arabs in Kuwait

Al Samarrai, A.R 220

Dopaminergic Interplexiform Cells Displaced to the Ganglion Cell Layer in the Rat

Retina

Moussafi, F.; Savy, C; Nguyen-Legros, J 224

Plasmin and Epidermal Growth Factor in the Tear Fluid of Contact-Lens Wearers: Effect of Wearing Different Types of Contact Lenses and Association with Clinical Findings

Setten, G.-B. van; Tervo, T.; Andersson, R.; Perheentupa, J.; Tarkkanen, A 233

Decolouration of the Lens Pigment in Senile Nuclear Cataract

Truscott, R.J.W.; Martinez, M.G 241

Effects of Mifepristone on Rabbit Intraocular Pressure in the Presence and Absence of

Dexamethasone

Green, K.; Cheeks, L.; Slagle, T.; Phillips, C.I

247

Comparison of the Effects of Argon and Neodymium:YAG Laser Iridotomy on Prostaglan-

din Ej and Blood-Aqueous Barrier Disruption

Naveh, N.; Rosner, M.; Zborowsky-Gutman, L.; Rosen, N.; Weissman, C 253

End-Stage Fibrosis of the Lateral Rectus Muscle in Myopia with Esotropia. An Ultrastructural Study

Meyer, E.; Ludatscher, R.M.; Lichtig, C; Shauly, Y.; Gdal-On, M 259

Increased Glucose Content in the Aqueous Humour Caused by the Use of Xylazine

Arnbjerg, J.; Eriksen, T 265

No. 5 Tear Cholesterol Levels in Blepharitis

Saatçi, A.O.; ïrkeç, M.; Ünlü, N 269

Development of Light Dissemination in the Rat Lens after in vivo Exposure to Radiation in the 300-nm Wavelength Region

Söderberg, P.G 271

Spatial Selectivity of Pattern Electroretinogram Components

Yoshii, M.; Dodt, E 280

Ocular Blood Flow and Vascular Permeability in Endotoxin-Induced Inflammation

Green, K.; Paterson, C.A.; Cheeks, L.; Slagle, T.; Jay, W.M.; Aziz, M.Z 287

Ankyrin of the Ocular Lens

Dola, A.; Ktar, M.; Hussain, P.; Maisel, H 295

Intralenticular Water Interactions with Phosphates in the Intact Crystalline Lens

Glonek, T.; Greiner, J.V 302

Cellular Immune Response to la Induction by Intraocular Gamma-Interferon

Lee, S.F.; Pepose, J.S 310

Cicletanine and Hypertensive Retinopathy

Ruchoux, M.-M.; Droy-Lefaix, M.-T.; Bakri, F.; Guillemain, J.; Ruchoux, P.;

Autret, A 318

Uveitis Induced by Various Cross-Reactive Antigens in Guinea Pigs

Sasaki, K.; Sanui, H.; Inomata, H 330

VI Contents

No. 6 Effect of Calcium Channel Blockers on Intraocular Pressure 
Payne, L.J.; Slagle, T.M.; Cheeks, L.T.; Green, K 337

Distribution of Glycosyltransferase in Bovine Eyes

Unoki, K.; Uehara, F.; Muramatsu, T 342

Effect of Topical Dexamethasone on the Ocular Allergic Reaction in Passively Sensitized

Guinea Pigs

Mehta, M.C.; Calonge, M.C.; Levene, R.B.; Bloch, K.J.; Allansmith, M.R 351

Pharmacodynamics of Amlexanox (AA-673) in Normal and Anaphylactic Rat Conjunctiva and Its Effect on Histamine Concentration

Rankov, G.; Sasaki, K.; Fukuda, M 359

Ultraviolet-Induced Changes in Corneal Transmission Properties and Influence on

Scheimpflug Photography

Schmidt, J.; Brettner, S.; Wegener, A.; Hockwin, 0365

Histopathologic and Immunohistochemical Findings in Gelatinous Drop-Like Corneal

Dystrophy

Akiya, S.; Furukawa, H.; Sakamoto, H.; Takahashi, H.; Sakka, Y 371

Timed Biomicroscopy of Rabbit Corneal Wound Repair

Fernandez del Cotero, J. del; Bonafonte, S.; Aguirre Vila-Coro, A.A

Effect of Optical Defocus on the Steady State Pattern Reversal Visual-Evoked Response

Katsumi, O.; Hirose, T.; Sakaue, H.; Mehta, M.; Rosenstein, R.B 383

Visually Evoked Potentials in Response to Rotating Plane-Polarized Blue Light

Dodt, E.; Kuba, M 391

A. Author Index 395

Subject Index 397 